\title{
ДЕЯКІ ПИТАННЯ НАДЗВИЧАЙНИХ СИТУАЦІЙ ТЕХНОГЕННОГО ТА ПРИРОДНОГО ХАРАКТЕРУ В УКРАЇНІ (ОГЛЯД ЛІТЕРАТУРИ)
}

\author{
ДУ «Український інститут стратегічних досліджень Міністерства охорони здоров’я України», м. Київ, \\ Україна
}

\begin{abstract}
Мета: висвітлити деякі питання надзвичайних ситуацій техногенного та природного характеру на основі вивчення літературних джерел.

Матеріали і методи. Застосовано бібліосемантичний та аналітичний методи.

Результати. Значне антропогенне і техногенне навантаження території України, зростання ризиків виникнення надзвичайних ситуацій техногенного та природного характеру, загострення стану гідротехнічних споруд, з одного боку, та відсутність загальноприйнятих поглядів щодо цільових, фрункціональних, організаційних та інших складових механізмів державного управління у галузі медичного захисту за умов надзвичайних ситуацій техногенного та природного характеру, а саме подолання медико-санітарних наслідків надзвичайних ситуацій, збереження життя і здоров'я людей - 3 іншого зумовлює необхідність науково-теоретичного обґрунтування й розробки Програми їх подолання та попередження.

Висновки. Забезпечення сталого соціально-економічного розвитку України має супроводжуватися формуванням безпечного для суспільства і кожної людини стану життєвого довкілля, забезпеченням сучасної системи безпеки, яка б ґрунтувалася на принципах міжнародного права, та координувалась Програмою реагування галузі охорони здоров'я на надзвичайні ситуації.
\end{abstract}

КЛЮЧОВІ СЛОВА: надзвичайні ситуації; життєдіяльність людства; законодавство; цивільний захист населення.

Надзвичайні ситуації завжди супроводжували існування людства, нерідко через них зникали держави та цивілізації. На сьогодні надзвичайні ситуації не менше загрожують людству, ніж сотні й тисячі років тому. Наукові дослідження свідчать, що в подальшому спостерігатиметься збільшення загальної кількості надзвичайних ситуацій, масштабності їх наслідків, у тому числі для життя і здоров'я людей та розміру збитків.

Останнє століття характеризується не тільки зростанням надзвичайних ситуацій техногенного характеру з катастрофічними наслідками, але й значною кількістю надзвичайних ситуацій природного характеру, в яких, за умов мирного часу, гине значно більше людей, ніж внаслідок техногенних [9].

На сьогодні вже стало аксіомою, що людство протягом певного часу, особливо в другій половині XX та XXI ст., живе у розладі з природою і цей розлад виявляється згубним не тільки для навколишнього середовища, а й для всього населення планети. Внаслідок розвитку суспільства позитивні, на перший погляд, зрушення в забезпеченні вищого рівня життя людини призвели одночасно до суттєвого підвищення ризику втрати здоров'я, стати жертвою або постраждати в надзвичайній ситуації. Реальністю стала загроза існування людства на Землі [3].

(с) Л.М. Пазинич, О.Р. Ситенко, Т.М. Смірнова, 2018
У пошуках шляхів зменшення негативів повсякдення варто згадати праці великих українців В. Вернадського і С. Подолинського про нерозривний взаємозв'язок між неживою речовиною, 3 одного боку, живим, органічним світом - 3 іншого, і антропогенним, людським, соціальним компонентом. Україна на сьогодні, на жаль, є одним із найнебезпечніших регіонів світу за ступенем критичності техногенних навантажень, потенційної небезпеки шкідливих для населення і навколишнього середовища виробництв [10].

У зовсім недалекому минулому, навіть на початку XX ст., головними чинниками масової гибелі людей у мирний час були несприятливі природні, біологічні та соціальні катаклізми: землетруси, повені, цунамі, голодомори, інорекційні захворювання тощо. Актуальність та їх значущість не знижуються й нині, оскільки тяжкість наслідків природних катаклізмів зросла в XX ст. у 7-8 разів, порівняно з позаминулим століттям, що $є$ результатом потужного антропогенного впливу життєдіяльності людства на зовнішнє середовище.

Мета роботи: висвітлити деякі питання надзвичайних ситуацій техногенного та природного характеру на основі вивчення літературних джерел.

Матеріали і методи. Застосовано бібліосемантичний та аналітичний методи.

Результати дослідження та їх обговорення. Спеціалісти більшості країн світу одностайні в 
тому, що людство вже стоїть біля фратальної межі, за якою руйнування природних систем та постійні техногенні катастрофри, що набувають все більш нищівного та масового характеру, поховають під своїми уламками всі інші проблеми людства.

Під терміном «аварія» розуміють небезпечну подію техногенного характеру, що створює на об'єкті, території або акваторії загрозу для життя і здоров'я людей, призводить до руйнування будівель, споруд, обладнання та транспортних засобів, порушення виробничого або транспортного процесу чи завдає шкоди довкіллю.

Катастрофра - це великомасштабна аварія чи інша подія, що призводить до тяжких трагічних наслідків.

Надзвичайна ситуація (НC) - це порушення нормальних умов життя і діяльності людей, спричинене аварією, епідемією, стихійним лихом тощо. Тобто явище при якому відбуваються численні збитки у народному господарстві, а насамперед руйнується людське життя [1].

Надзвичайні ситуації класифрікують за характером походження, ступенем поширення, розміром людських втрат і матеріальних збитків.

Постановою Кабінету Міністрів України № 1099 «Про порядок класифікації надзвичайних ситуацій» затверджено «Положення про класифікацію надзвичайних ситуацій» [11].

Відповідно до характеру походження подій, що можуть зумовити виникнення надзвичайних ситуацій на території України, розрізняють:

- надзвичайні ситуації техногенного характеру: транспортні аварії (катастрофри), пожежі, неспровоковані вибухи чи їх загроза, аварії з викидом (загрозою викиду) небезпечних хімічних, радіоактивних, біологічних речовин, раптове руйнування споруд та будівель, аварії на інженерних мережах і спорудах життєзабезпечення, гідродинамічні аварії на греблях, дамбах тощо;

- надзвичайні ситуації природного характеру: небезпечні геологічні, метеорологічні, гідрологічні морські та прісноводні явища, деградація ґрунтів чи надр, природні пожежі, зміна стану повітряного басейну, інфекційна захворюваність людей, сільськогосподарських тварин, масове ураження сільськогосподарських рослин хворобами чи шкідниками, зміна стану водних ресурсів та біосфери тощо;

- надзвичайні ситуації соціально-політичного характеру, пов'язані з протиправними діями терористичного і антиконституційного спрямування: здійснення або реальна загроза терористичного акту (збройний напад, захоплення і затримання важливих об'єктів, ядерних установок і матеріалів, систем зв'язку та телекомунікацій, напад чи замах на екіпаж повітряного чи морського суден), викрадення (спроба викрадення) чи знищення суден, захоплення, встановлення вибухових пристроїв у громадських місцях, зникнення (крадіжка) зброї, виявлення застарілих боєприпасів тощо;

- надзвичайні ситуації воєнного характеру, пов'язані з наслідками застосування зброї масового ураження або звичайних засобів ураження, під час яких виникають вторинні фрактори ураження населення внаслідок руйнування атомних і гідроелектричних станцій, складів і сховищ радіоактивних і токсичних речовин та відходів, нафтопродуктів, вибухівки, сильнодіючих отруйних речовин, токсичних відходів, транспортних та інженерних комунікацій тощо.

Крім того, необхідно знати, що, відповідно до територіального поширення, обсягів, заподіяних або очікуваних економічних збитків, кількості людей, які загинули, за класифрікаційними ознаками визначають чотири рівні надзвичайних ситуацій:

1) надзвичайна ситуація загальнодержавного рівня - це надзвичайна ситуація, яка розвивається на території двох та більше областей (Автономної Республіки Крим, міст Києва та Севастополя) або загрожує транскордонним поширенням, а також у разі, коли для її ліквідації необхідні матеріали і технічні ресурси в обсягах, що перевищують власні можливості окремої області (Автономної Республіки Крим, міст Києва та Севастополя), але не менше одного відсотка обсягу видатків відповідного бюджету;

2) надзвичайна ситуація регіонального рівня - це надзвичайна ситуація, яка розвивається на території двох або більше адміністративних районів (міст обласного значення) - Автономної Республіки Крим, областей, міст Києва та Севастополя, або загрожує поширенням на територію суміжної області України, а також у разі, коли для її ліквідації необхідні матеріальні й технічні ресурси в обсягах, що перевищують власні можливості окремого району, але не менше одного відсотка обсягу видатків відповідного бюджету;

3) надзвичайна ситуація місцевого рівня - це надзвичайна ситуація, яка виходить за межі потенційно небезпечного об'єкта, загрожує поширенням самої ситуації або її вторинних наслідків на довкілля, сусідні населені пункти, інженерні споруди, а також у разі, коли для її ліквідації необхідні матеріальні й технічні ресурси в обсягах, що перевищують власні можливості потенційно небезпечного об'єкта, але не менш одного відсотка обсягу видатків відповідного бюджету. До місцевого рівня також належать всі надзвичайні ситуації, які виникають на об'єктах житловокомунальної сорери та інших, що не входять до затверджених переліків потенційно небезпечних об'єктів;

4) надзвичайна ситуація об'єктного рівня - це надзвичайна ситуація, яка розгортається на території об'єкта або на самому об'єкті й наслідки 
не виходять за межі об'єкта або його санітарнозахисної зони $[9,11]$.

Сучасний розвиток України за умов системної трансформації характеризується як перманентно складний. Глобальний розвиток людської цивілізації, крім позитивних надбань, призвів до розвитку чисельних загроз життєво важливим інтересам людини і громадянина, суспільства і держави. Значне місце серед цих загроз займає небезпека техногенно-природного характеру, притаманна й Україні. У зв'язку з цим, велику роль у забезпеченні техногенної та природної безпеки відводять саме Єдиній державній системі цивільного захисту населення і територій [4].

Достатньо нагадати про глобальну техногенну катастрофу на Чорнобильській AEC, масштабні землетруси, повені, цунамі та буревії (торнадо) у багатьох країнах світу з численними людськими жертвами.

Забезпечення безпеки населення в надзвичайних ситуаціях, зумовлених стихійним лихом, техногенними аваріями і катастрофрами, а також використанням сучасної зброї (воєнні надзвичайні ситуації), є загальнодержавним завданням, обов'язковим для вирішення всіма територіальними та відомчими органами управління, службами, фрормуваннями, а також суб'єктами господарювання.

Законодавство України у сорері захисту населення від НС техногенного та природного характеру ґрунтується на Конституції України, Законах України «Про захист населення і території від надзвичайних ситуацій техногенного та природного характеру», «Про правовий режим надзвичайного стану» та інших нормативно-правових актах.

Підготовку до дій для захисту населення в надзвичайних ситуаціях необхідно планувати і виконувати диференційовано за видами і ступенями можливої небезпеки, а саме:

- організувати й здійснювати згідно з принципами, основними з яких є пріоритетність завдань, спрямованих на рятування людей та збереження довкілля;

- безумовно надавати перевагу раціональній та превентивній безпеці;

- забезпечити вільний доступ населення до інорормації про захист населення і територій;

- приділяти особливу увагу щодо відповідальності громадян про власну безпеку, неухильне дотримання ними правил безпеки та дій в надзвичайних ситуаціях;

- нести відповідальність у межах своїх повноважень посадовим особам за дотримання вимог закону; обов'язкова та завчасна реалізація заходів, спрямованих на запобігання виникненню надзвичайних ситуацій техногенного і природного характеру та мінімізація їх негативних психосоціальних наслідків;
- враховувати економічні, природні та інші особливості територій і ступені реальної небезпеки виникнення надзвичайних ситуацій;

- максимально можливо, ефективно і комплексно використовувати наявні сили і способи, що призначені для запобігання надзвичайним ситуаціям і реагування на них [7].

Підготовку до дій для захисту населення в НС необхідно планувати і виконувати диференційовано за видами і ступенями можливої небезпеки на конкретних територіях і з урахуванням насиченості цих територій об'єктами промислового призначення, гідроспорудами і системами виробничої та соціальної інфраструктури, потужностей і розміщення потенційно небезпечних об'єктів, наявності захисних споруд, особливостей розселення жителів, кліматичних та інших місцевих фракторів.

Значне антропогенне і техногенне навантаження території України, зростання ризиків виникнення надзвичайних ситуацій природного і техногенного характеру, загострення стану гідротехнічних споруд, з одного боку, та відсутність загальноприйнятих поглядів щодо цільових, фрункціональних, організаційних та інших складових механізмів державного управління у галузі медичного захисту за умов надзвичайних ситуацій природного і техногенного характеру, а саме подолання медико-санітарних наслідків надзвичайних ситуацій, збереження життя і здоров'я людей 3 іншого зумовлює необхідність науково-теоретичного обґрунтування [7].

Закон України «Про захист населення і територій від надзвичайних ситуацій технічного та природного характеру» [6] містить ст. 13 «Медичний захист», та відносить медичний захист до галузі компетенції ДСМК. У ст. 13 цього закону перераховані такі заходи запобігання або зменшення ступеня ураження людей, своєчасне надання допомоги постраждалим та їх лікування, забезпечення епідемічного благополуччя в зонах НC:

- планування і використання існуючих сил та засобів закладів охорони здоров'я незалежно від фрорм власності та господарювання;

- введення в дію Національного плану соціально-психологічних заходів при виникненні та подолання надзвичайних ситуацій природного i техногенного характеру;

- розгортання в умовах НС природного і техногенного характеру необхідної кількості лікувальних закладів;

- завчасне застосування профрілактичних медичних препаратів та санітарно-епідеміологічних заходів;

- контроль за якістю харчових продуктів і продовольчої сировини, питної води і джерелами водопостачання;

- контроль за станом атмосфрерного повітря та опадів; 
- завчасне створення і підготовка спеціальних медичних фрормувань;

- накопичення медичних засобів захисту медичного та спеціального майна і техніки;

- контроль за станом довкілля, санітарно-гігієнічною та епідемічною ситуацією.

Для охорони здоров'я населення у подібних випадках існує медицина катастроф - це підрозділ, що забезпечує надання екстреної медичної допомоги при різних видах надзвичайних подій.

Служба медицини катастроф має завдання та організаційну структуру. Ї̈̈ відрізняє від інших галузей медицини організація чіткої роботи етапів виконання лікувальних заходів, що дозволяє надати невідкладну допомогу одночасно більшій кількості людей. До складу Служби медицини катастроф входять центри медичної допомоги, медичні фрормування, лікувальні заклади та спеціалізовані бригади постійної готовності [1].

Прописано протоколи організації етапів надання екстреної медичної допомоги при різних видах HC. Проводиться медико-тактична характеристика фракторів, які завдають негативний вплив на організацію медичної допомоги. Характеристика складається на основі наявності чинників, діючих у вогнищі ураження.

Існують базові принципи надання медичної допомоги, комплекс санітарно-гігієнічних, лікувальних, евакуаційних заходів, що надаються постраждалим. При цьому враховується як необхідність надати допомогу якомога більшої кількості постраждалих, так й зберегти здоров'я медиків, які працюють у зоні катастрофи. Передбачено двоетапне лікувально-евакуаційне забезпечення: безпосередньо біля вогнища НC (або в ньому, якщо це можливо) відбувається надання невідкладної допомоги, евакотранспортне сортування та евакуація постраждалих. Другий етап передбачає отримання постраждалими кваліфікованої допомоги вже у лікувальному закладі. Підвищенню ефективності роботи бригад, що залучені до лікувально-евакуаційного забезпечення, надає уніфікація засобів та методів допомоги, що базуються на положеннях військової польової хірургії. Виділено фрази надання першої допомоги постраждалим: перша фраза - ізоляція, це етап до проведення рятувальних робіт, безпосередньо у момент виникнення надзвичайної ситуації; друга фраза - рятування, відзначається початком рятувальних робіт та закінчується після евакуації постраждалих із зони катастрофри; третя - відновлення, відбувається вже у лікувальному закладі [2].

Організація лікувально-евакуаційного забезпечення передбачає чітке виконання обов'язків. Так бригади швидкої допомоги, які не були задіяні на викликах, прибувають на місце НС першими. Окрім надання допомоги, до обов'язків медиків входить збір інфрормації стосовно кількості постраждалих, тяжкості уражень, наявності травм. Збирається медико-тактична характеристика фракторів НС, 3'ясовується загальна ситуація в колі ураження. Після обробки отриманої інфрормації на місце прибувають медичні бригади, що мають засоби для надання допомоги, враховуючи до якого виду належить НC (радіаційне, хімічне, механічне, термічне ураження тощо). При необхідності прибувають спеціалізовані медичні бригади, розгортаються мобільні госпіталі, залучаються до роботи працівники інших відомств. Розробка алгоритмів надання невідкладної медичної допомоги постраждалим та суворе дотримання принципів організації роботи медиків у екстремальних умовах надзвичайної ситуації значно підвищує кількість людей, які отримують кваліфіковану допомогу вчасно, що $є$ запорукою їх подальшого одужання. Усі медичні заклади, незалежно від відомчої належності та форми власності, розташовані на певній адміністративній території, здійснюють лікувально-профрілактичну діяльність і обслуговують певні верстви населення, які проживають чи працюють на даній адміністративній території. Всі ці заклади утворюють єдиний медичний простір і єдину інфрраструктуру, яка згідно з діючим законодавством, взаємодіє в повсякденній обстановці та за умов надзвичайної ситуації [8].

3 метою ефективної реалізації завдань цивільного захисту, зменшення матеріальних витрат та недопущення шкоди об'єктам, матеріальним й культурним цінностям та довкіллю в разі виникнення НС природного, техногенного і соціального характеру центральні та місцеві ограни виконавчої влади, органи місцевого самоврядування, підпорядковані їм сили та засоби, підприємства, установи та організації незалежно від форм власності, добровільні рятувальні формування здійснюють оповіщення та інформування, спостереження та лабораторний контроль, укриття у захисних спорудах, евакуацію, інженерний, медичний, психологічний, біологічний, екологічний, радіаційний та хімічний захист [5].

Різні за фрахом та політичними вподобаннями науковці одностайні в тому, що руйнування навколишнього середовища $€$ наслідком науковотехнічного процесу людства, що спричинив кризу. Це криза однобічної, суто технічної орієнтації людства і вибір помилкової та руйнівної стратегії підкорення природи, що призвело до розриву органічної єдності людства з біоенергетичним середовищем, яке його живить, i, врешті-решт, призведе до трагічних наслідків.

\section{Висновки}

Забезпечення сталого соціально-економічного розвитку України має супроводжуватися фрормуванням безпечного для суспільства і кожної людини стану життєвого довкілля, забезпеченням 
прийнятого рівня ризику, сучасною системою безпеки, яка б ґрунтувалася на принципах міжнародного права, та координувалась Програмою реагування галузі охорони здоров'я на надзвичайні ситуації.
Перспективи подальших досліджень полягають у використанні отриманого світового досвіду в подальшій роботі з впровадження безпечного для суспільства і кожної людини стану життєвого довкілля.

\section{Список літератури}

1. Бобро О. В. Організація медико-санітарного забезпечення населення при різних видах надзвичайних ситуацій / О. В. Бобро, С. С. Шепеленко // Проблеми цивільного захисту населення та безпеки життєдіяльності: сучасні реалії України : матеріали III Всеукраїнської заочної науково-практичної конференції, 21 квітня 2017 р. - К., 2017. - С. 17-18. 2. Головіна Н. В. Правовий захист населення від надзвичайних ситуацій техногенного та природного характеру / Н. В. Головіна // Проблеми цивільного захисту населення та безпеки життєдіяльності: сучасні реалії України : матеріали III Всеукраїнської заочної науково-практичної конференціії, 21 квітня 2017 р. - К., 2017. - С. 41-42.

3. Організація та управління процесом надання медичної допомоги постраждалим внаслідок землетрусів : монографрія / С. О. Гур'єв, П. Б. Волянський, А. В. Трент'єва [та ін.]. - Інститут державного управління у ссрері цивільного захисту МНС України, Український науково-практичний центр екстреної медичної допомоги та медицини катастрофр МОЗ України. - К., 2008. - С. 3.

4. Гур'єв С. О. Реагування на виникнення надзвичайних ситуацій : монографрія / С. О. Гур'єв. - Вінниця, 2010. - С. 6. 5. Дубицький А. Ю. Медицина катастроф / А. Ю. Дубицький, І. О. Семенов, Л. П. Чепкий. - К. : КУРС, 2013. С. 42-49.

6. Закон України «Про захист населення і територій від надзвичайних ситуацій технічного та природного характеру» [Електронний ресурс] // Ооріційний сайт. - 2007. - Режим доступу : http://zakon1.rada.gov.ua/cgibin/laws/main. cgi?nreg=1809-14

7. Каленська В. П. Медико-санітарний захист та забезпечення населення на випадок надзвичайних ситуацій / В. П. Каленська // Проблеми цивільного захисту населення та безпеки життєдіяльності: сучасні реалії України : матеріали III Всеукраїнської заочної науково-практичної коноеренціїї, 21 квітня 2017 р. - К., 2017 - С. 61-64.

8. Компанець В. С. медицина надзвичайних ситуацій / В. С. Компанець, Н. Д. Корольова. - К. : Вінниця, 2009. C. $108-140$.

9. Кочін І. В. Медицина катастроф : виробниче видання / І. В. Кочін, Г. О. Черняков, П. І. Сидоренко ; за ред. І. В. Кочіна. - К. : Здоров'я, 2008. - 724 с.

10. Медичне постачання формувань і закладів Державної служби медицини катастроф України : методичні рекомендації / А. П. Картиш, Г. Г. Рощін, В. О. Волошин [та ін.]. - К. : МОЗ України, УНПЦ ЕМД та МК, КМАПО ім. П. Л. Шупика, 1999. - 158 с.

11. Про порядок класифікації надзвичайних ситуацій : Постанова Кабінету Міністрів України № 1099 [Електронний ресурс] // Офріційний сайт. - 1998. - Режим доступу : http://zakon0.rada.gov.ua/laws/show/1099-98-п

\section{References}

1. Bobro, O.V., \& Shepelenko, S.S. (2017). Orhanizatsiia medyko-sanitarnoho zabezpechennia naselennia pry riznykh vydakh nadzvychainykh sytuatsii [Organization of medical and sanitary maintenance of the population at various types of emergencies]. Problemy tsyvilnoho zakhystu naselennia ta bezpeky zhyttiediialnosti: suchasni realii Ukrainy. Materialy III Vseukrainskoi zaochnoi naukovo-praktychnoi konferentsii - Problems of Civil Protection of Population and Safety of Life: Modern Realities of Ukraine: Materials of the Third All-Ukrainian Correspondence Scientific and Practical Conference. Kyiv [in Ukrainian].

2. Holovina, N.V. (2017). Pravovyi zakhyst naselennia vid nadzvychainykh sytuatsii tekhnohennoho ta pryrodnoho kharakteru [Legal protection of the population from man-made and natural emergencies]. Problemy tsyvilnoho zakhystu naselennia ta bezpeky zhyttiediialnosti: suchasni realii Ukrainy. Materialy III Vseukrainskoi zaochnoi naukovo-praktychnoi konferentsii - Problems of Civil Protection of Population and Safety of Life: Modern Realities of Ukraine: Materials of the Third All-Ukrainian Correspondence Scientific and Practical Conference. Kyiv [in Ukrainin].

3. Huriev, S.O., Volianskyi, P.B., Trentieva, A.V., Satsyk, S.P., \& Hrinenko, Yu.O. (2008). Orhanizatsiia ta upravlinnia protsesom nadannia medychnoi dopomohy postrazhdalym vnaslidok zemletrusiv: Monohrafiia [Organization and management of the process of providing medical care to the victims of earthquakes: a monograph]. Instytut derzhavnoho upravlinnia u sferi tsyvilnoho zakhystu MNS Ukrainy, Ukrainskyi naukovo-praktychnyi tsentr ekstrenoi medychnoi dopomohy ta medytsyny katastrof MOZ Ukrainy - Institute of Public Administration in the field of civil protection of the Ministry of Emergencies of Ukraine, Ukrainian Scientific and Practical Center of Emergency Medical Care and Disaster Medicine Ministry of Health of Ukraine. Kyiv [in Ukrainian].

4. Huriev, S.O. (2010). Reahuvannia na vynyknennia nadzvychainykh sytuatsii: Monohrafiia [Emergency response: Monograph]. Vinnytsia [in Ukrainian].

5. Dubytskyi, A.Yu., Semenov, A.Yu., \& Chepkyi, L.P. (2013). Medytsyna katastrof [Medicine of catastrophes]. Kyiv: KURS [in Ukrainian].

6. Zakon Ukrainy "Pro zakhyst naselennia i terytorii vid nadzvychainykh sytuatsii tekhnichnoho ta pryrodnoho kharakteru" [Law of Ukraine "On Protection of Population and Territories from Emergencies of Technical and Natural Character"]. Retrieved from: http://zakon1.rada.gov.ua/cgi-bin/laws/main.cgi?nreg=1809-14

7. Kalenska, V.P. (2017). Medyko-sanitarnyi zakhyst ta zabezpechennia naselennia na vypadok nadzvychainykh sytuatsii [Medical and sanitary protection and provision of population in the event of emergencies]. Problemy tsyvilnoho zakhystu 
naselennia ta bezpeky zhyttiediialnosti: suchasni realii Ukrainy. Materialy III Vseukrainskoi zaochnoi naukovo-praktychnoi konferentsii - Problems of Civil Protection of Population and Safety of Life: Modern Realities of Ukraine: Materials of the Third All-Ukrainian Correspondence Scientific and Practical Conference. Kyiv [in Ukrainian].

8. Kompanets, V.S., \& Korolova, N.D. (2009). Medytsyna nadzvychainykh sytuatsii [Medicine of Emergencies]. Kyiv: Vinnytsia [in Ukrainian].

9. Kochin, I.V. (Ed.), Cherniakov, H.O., Sydorenko, P.I. Medytsyna katastrof: Vyrobnyche vydannia [Disaster Medicine: Production Edition]. Kyiv: Zdorovia [in Ukrainian].

10. Kartysh, A.P., Roshchin, H.H., Voloshyn, V.O., Mykhailovskyi, M.M., Terentieva, A.V. [et al.] Medychne postachannia formuvan i zakladiv Derzhavnoi sluzhby medytsyny katastrof Ukrainy (Metodychni rekomendatsii) [Medical Supply of Formations and Facilities of the State Service of Medicine of Disasters of Ukraine: methodical recommendations]. Kyiv: MOZ Ukrainy KMAPO im. P.L. Shupyka [in Ukrainiuan].

11. Postanova Kabinetu Ministriv Ukrainy № 1099 "Pro poriadok klasyfikatsii nadzvychainykh sytuatsii" ["On the procedure for classification of emergencies". Resolution of the Cabinet of Ministers of Ukraine No. 1099]. - Retrieved from: http:// zakon0.rada.gov.ua/laws/show/1099-98-p

\section{НЕКОТОРЫЕ ВОПРОСЫ ЧРЕЗВЫЧАЙНЫХ СИТУАЦИЙ ТЕХНОГЕННОГО И ПРИРОДНОГО ХАРАКТЕРА В УКРАИНЕ (ОБЗОР ЛИТЕРАТУРЫ)}

Л.Н. Пазинич, Е.Р. Ситенко, Т.Н. Смирнова

ГУ «Украинский институт стратегических исследований Министерства здравоохранения Украины», г. Киев, Украина

Цель: осветить некоторые вопросы чрезвычайных ситуаций техногенного и природного характера на основании изучения литературных источников.

Материалы и методы. Применен библиосемантический и аналитический методы.

Результаты. Значительные антропогенные и техногенные нагрузки территории Украины, рост рисков возникновения чрезвычайных ситуаций природного и техногенного характера, отсутствие общепринятых взглядов относительно целевых, функциональных, организационных и других механизмов государственного управления в сорере медицинской защиты в условиях чрезвычайных ситуаций природного и техногенного характера, все это обусловливает необходимость научно-теоретического обоснования и разработки Программы их преодоления и предупреждения.

Выводы. Обеспечения устойчивого социально-экономического развития Украины должно сопровождаться формированием безопасного для общества и каждого человека состояния окружающей среды для жизни, которая базировалась на принципах международного права, и координировалась Программой реагирования здравоохранения на чрезвычайные ситуации.

КЛЮЧЕВЫЕ СЛОВА: чрезвычайные ситуации; жизнедеятельность человечества; законодательство; гражданская защита населения.

\section{SOME QUESTIONS OF EMERGENCY SITUATIONS OF TECHNOGENIC AND NATURAL CHARACTER IN UKRAINE (LITERATURE REVIEW)}

I.M. Pazynych, O.R. Sytenko, T.M. Smirnova

Ukrainian Institute of Strategic Researches of the Ministry of Health of Ukraine, Kyiv, Ukraine

Purpose: to take up some questions of emergency situations of technogenic and natural character on the basis of references studying.

Materials and Methods. Bibliosemantic and analytical methods are applied.

Results. Significant anthropogenic and technogenic loading of the territory of Ukraine, increasing the risks of emergency situations of natural and technogenic character, lack of generally accepted views on the target, functional, organizational and other mechanisms of state administration in the field of medical protection in the conditions of the ES of natural and technogenic character, all this causes need of scientifically and theoretical substantiation and development of the Program for their overcoming and prevention.

Conclusions. Ensuring sustainable social and economic development of Ukraine should be accompanied by formation safe environment for society and each person, based on the principles of international law, and was coordinated by the Program of health care response to emergency situations.

KEY WORDS: emergency situations; vital activity of mankind; legislation, civil protection of the population.

Рукопис надійшов до редакції 01.06.2018

\section{Відомості про авторів:}

Пазинич Лариса Миколаївна - науковий співробітник науково-організаційного відділу дУ «Український інститут стратегічних досліджень Міністерства охорони здоров'я України».

Ситенко Олена Ростиславівна - кандидат медичних наук, старший науковий співробітник, завідувач науковоорганізаційного відділу ДУ «Український інститут стратегічних досліджень Міністерства охорони здоров'я України». Смірнова Тетяна Миколаївна - старший науковий співробітник науково-організаційного відділу ДУ «Український інститут стратегічних досліджень Міністерства охорони здоров'я України». 